The effect of patent enforcement strength and FDI on economic growth

\begin{tabular}{|r|l|}
\hline Journal: & Multinational Business Review \\
\hline Manuscript ID & MBR-07-2016-0024.R1 \\
\hline Manuscript Type: & Research Paper \\
\hline Keywords: & $\begin{array}{l}\text { Intellectual Property, FDI, Economic Growth, TRIPS, Patent systems, } \\
\text { Patent enforcement }\end{array}$ \\
\hline Authors: & Constantinos Alexiou, Joseph G. Nellis J, Nikolaos Papageorgiadis \\
\hline
\end{tabular}


The Effect of Patent Enforcement Strength and FDI on Economic Growth

\begin{abstract}
The level of effectiveness of patent enforcement in a country's patent system is a key area of focus in recent international trade negotiations, such as the Trans-Pacific Partnership Agreement. Since the implementation of the Trade-Related Aspects of Intellectual Property Rights (TRIPS) agreement by most developed and developing countries, the focus of such international negotiations has now shifted from expanding provisions related to patent law protection towards provisions that can enhance the effectiveness of patent enforcement in negotiating countries. While these policy-making efforts are driven by an inherent assumption that stronger levels of patent enforcement will positively affect international trade and boost economic growth for countries adopting such reforms, there is currently no empirical evidence to support or oppose this assumption. This paper studies the effect of the strength of patent enforcement on the economic growth of 42 developed and developing countries in the post-TRIPS years 1998-2011, as well as the role of inward foreign direct investment (FDI) in mediating and enhancing this relationship. The results of this study provide support to the policymaking expectations adopted in the negotiations of free trade agreements, in that stronger levels of patent enforcement are found to have a significantly positive effect on the economic growth of both developed and developing countries. Importantly, inward FDI flows have a mediating role in positively boosting this effect for all countries in our sample, and particularly for developed countries.
\end{abstract}

Keywords: Patent systems, patent enforcement, intellectual property, FDI, economic growth, TRIPS 


\section{The Effect of Patent Enforcement Strength and FDI on Economic Growth}

"Intellectual Property (IP) is a key driver of innovation and economic growth (...) but we need to understand better the relationship between IPRs and economic value. (...) One of the difficulties (...) is the lack of clear evidence around the relationship between IP and economic development, although there is evidence to show that the role of IP does change as countries develop."

(UK Intellectual Property Office, 2011, p. 3-4).

\section{Introduction}

This paper explores the effect of patent enforcement strength on the economic growth of developed and developing countries and the role of inward FDI in mediating this relationship in the years 1998-2011, since the signing of the Trade-Related Aspects of Intellectual Property Rights (TRIPS) agreement. ${ }^{1}$ Currently, policies involving the strengthening of national patent systems across countries play a central role in trade negotiations, such as the Trans-Pacific Partnership agreement (TPP), the Transatlantic Trade and Investment Partnership (TTIP) and the India-European Union free trade agreement (Europa.eu, 2013a). ${ }^{2}$ These treaties propose the adoption of a) stronger patent legislation that extends the minimum standards of patent legal protection set by the TRIPS agreement in 1994 and, importantly, b) the introduction of patent and other intellectual property (IP) enforcement-related provisions and obligations for signatory countries that are not covered by TRIPS (Fergusson and Vaughn, 2010). These initiatives aim to develop business environments with strong patent

\footnotetext{
${ }^{1}$ The TRIPS agreement was negotiated at the Uruguay Round of the General Agreement on Tariffs and Trade and signed by all 158 members of the World Trade Organization on the $\mathbf{1 5}^{\text {th }}$ of April 1994 in Marrakesh.

${ }^{2}$ The TPP is a free trade agreement currently negotiated among 12 countries: Australia, Brunei Darussalam, Canada, Chile, Japan, Malaysia, Mexico, New Zealand, Peru, Singapore, United States and Vietnam (USTR, 2013). The TTIP is a free trade agreement currently negotiated between the United States and the European Union, aiming to drive economic growth and job creation. The negotiations for the India-European Union free trade agreement started in June 2007, and the discussions currently include a number of outstanding issues, such as rules on IP and competition, as well as sustainable development (Europa.eu, 2016).
} 
enforcement systems which are expected to allow local and foreign businesses (which own such intangible assets) to confidently innovate, invest and commercialize their product offerings so that they can fully appropriate their investments in innovation (Yang, 2008, 2012; Yang and Sonmez, 2013). Policy-makers expect that such business environments will attract higher levels of inward FDI and boost international business activity and economic growth overall (Europa.eu, 2013b; UNCTAD, 2013; USTR, 2013).

The proposed new treaties, however, have received strong resistance and criticism from interest groups in both developing and developed countries. As highlighted by the UK's Intellectual Property Office (2011), while strong IPR and patent systems are generally considered to be beneficial for the economic growth of a given country, the extent of this relationship can be different for developed and developing economies. The interest groups argue that new policies, guiding actions towards stronger patent enforcement, can slow down economic growth and negatively affect the economic welfare of citizens in the signatory countries (Electronic Frontier Foundation, 2013; Europa.eu, 2013b; Pathak et al., 2013). This stems from the belief that provisions that expand patent law protection and strengthen the levels of patent enforcement could lead to higher levels of patent litigation costs for firms currently competing in an industry, and deter the entry of potentially new, innovative firms that are unable to cover the potential costs of patent litigation and enforcement (Clegg and Cross, 2000). In the absence of available empirical evidence to support the decision-making of policy-makers, a critical question arises concerning whether or not the signatory countries of such treaties should adopt stronger legal patent protection and strengthen their patent enforcement systems?

Similar to the existing free trade treaty negotiations such as TPP and TTIP, the signing of the TRIPS agreement was based on the fundamental premise that stronger patent protection will help TRIPS signatory countries achieve economic growth via higher inward 
FDI, knowledge transfer and local innovation (UNCTAD, 1996). The signatory parties have been required to adjust their patent systems in order to provide a set of minimum standards of patent protection in terms of legislation (Ghauri and Rao, 2009; Yang and Sonmez, 2013). In 1994, while the patent systems of many of the signatory countries were in a nascent state, they were required to develop into full-forming legislative systems within a relatively rapid time-frame (Maskus, 2000). ${ }^{3}$ Such minimum legal standards effectively resembled the standards offered by most developed countries at the time, and thus substantial changes were required for the legislative systems of developing countries (Deere, 2008; UNCTAD, 1996). By 2007 the vast majority of the signatory developing countries offered patent legal systems that were TRIPS compliant (Deere, 2008). ${ }^{4}$ Developed countries, on the other hand, further evolved their patent systems in terms of legal coverage and length of protection (Hargreaves, 2011). Overall, implementing the obligations of the TRIPS agreement across countries has led to a significant increase in the minimum levels of patent protection as offered in the legislation across countries (Park, 2008).

Contrary to the extensive provisions for patent law protection, the TRIPS agreement did not set minimum standards for the level and strength of enforcement of patent legislation in the signatory countries (Taubman et al., 2012). The enforcement aspect of the patent system is important, since the mere existence of a law does not necessarily guarantee the extent to which it will be actively enforced within a particular jurisdiction (Arora, 2009). While TRIPS sets clear legal obligations related to patent enforcement, such as preliminary injunctions, signatory countries are given the freedom to customize their enforcement activities accordingly (Deere, 2008). This has led to major differences in the implementation of patent enforcement efforts between different countries, resulting in varying degrees of

\footnotetext{
${ }^{3}$ With the exception of the least developed countries, which were initially offered an extension to implement the TRIPs requirements by July 1, 2013. On June 13, 2013 this date was further extended to July 1, 2021 (WTO, 2013).

${ }^{4}$ Notable exceptions in the lack of TRIPS compliance were India and China on data protection laws and China on weak copyright laws. We thank an anonymous reviewer for this comment.
} 
patent enforcement being offered across economies (Arora, 2009; Awokuse and Yin, 2010; Papageorgiadis et al., 2014).

While the emerging new landscape of global patent systems represents the outcome of the implementation of the TRIPS policies, the effect of such rapidly strengthened degrees of legal patent protection and diverse levels of patent enforcement strength on the economic growth of countries in the post TRIPS era is still unclear. Importantly, the role and effect of the patent enforcement strength dimension of the system has not been empirically tested to date, mainly due to the limited availability of suitable secondary datasets (Arora, 2009; Papageorgiadis et al., 2014). ${ }^{5}$ Studies to date have instead focused on the effect of the strength of patent law protection on economic growth mainly for the years prior to the implementation of TRIPS, using the Ginarte and Park (1997) index, and found a positive effect (e.g. Falvey et al., 2006; Gould and Gruben, 1996) or, when sub-dividing the samples into developed and developing countries, inconclusive results (e.g. Kim et al., 2012; Schneider, 2005).

This paper makes two contributions to the literature. First, we study the effect of national patent enforcement strength levels on the economic growth of developed and developing countries. We utilize a new index to proxy for the strength of the enforcement dimension of patent systems as developed by Papageorgiadis et al. (2014). The results reveal a highly significant positive relationship between the level of national patent enforcement strength and the economic growth of developed and developing countries when treated as sub-samples. However, this relationship appears to be insignificant in the estimation when the sub-sample countries are combined in the same dataset. This result highlights the second contribution of this study, namely that the relationship between patent enforcement strength

\footnotetext{
${ }^{5}$ While the most commonly used index of legal patent protection developed by Ginarte and Park (1997) includes a measurement category entitled enforcement mechanisms, this captures the availability of "law on the books" relating to the enforcement of patents and not "law in action" which relates to the level and extent that the enforcement-related actors of the patent system apply and enforce the patent laws in practice (Arora, 2009; Maskus, 2000; Park, 2008; Papageorgiadis et al., 2014).
} 
and economic growth may be mediated (for part of the dataset) by another variable - inward FDI flows. We allow inward FDI flows (which are consistently found to have a strong positive relationship with economic growth in our estimations) to interact with patent enforcement strength and find that stronger levels of patent enforcement in countries that receive high levels of inward FDI have a highly significant positive effect on economic growth. This highly significant positive relationship holds in the case of developed countries, while the mediating role of FDI is not significant for the economic growth of developing countries. This finding suggests that the economic growth of countries receiving high levels of inward FDI is significantly improved when they boast stronger levels of patent enforcement.

The two contributions of this paper have important theoretical and practitioner implications. Future studies on international patent systems need to theorize for the potentially different effects that the level of patent enforcement effectiveness of a country can have on economic growth compared to the effects of legal patent protection strength. Past studies on the effects of patent systems on economic growth assumed that countries providing relatively extensive (strong) patent legal frameworks in their jurisdictions would also effectively enforce these rights in practice. While this could be the case in the pre-TRIPS years, the results of this study showcase the importance of theoretically and empirically distinguishing the effects of patent enforcement effectiveness from the effects of the strength of legal patent protection. With regards to the implications for practitioners, the results provide strong evidence and support to the focus of recent free trade negotiations and agreements that aim to increase the level of effectiveness of patent in order to boost the economic growth of countries. The results reveal that developing and developed countries which reformed their patent systems and achieved higher levels of patent enforcement effectiveness after TRIPS attained higher 
levels of economic growth. In addition, the positive effect of higher levels of patent enforcement effectiveness on economic growth is found to be even stronger for countries which are recipients of high levels of FDI. Overall, the evidence provides support to existing free trade treaty negotiations and agreements that anticipate higher levels of economic growth for countries which focus on improving the effectiveness of patent enforcement in their jurisdictions.

The rest of the paper is organized as follows. Section 2 reviews the literature and examines the components of national patent systems, their interaction with inward FDI and the effects on the economic growth of countries. Section 3 sets out the methodology and empirical investigation. Section 4 reports and discusses the results, while Section 5 provides the concluding remarks.

\section{Literature review}

\subsection{Patent systems}

A national system to protect patents is a) grounded in the patent-related laws enacted that provide protection to such intangible assets and $b$ ) the structures, operations and activities that are responsible for effectively enforcing the granted patent (Yang and Sonmez, 2013). The strength of a patent system overall depends on the strength and effectiveness of each of the two aspects of the system. The strength of protection that patent laws provide to patent asset holders depends on the scope and duration of patent legislation. Strong patent-related laws can allow the granting of rights to multiple types of inventions, for a period of time that allows the appropriation of returns from the patent asset in question, and provides a supportive legal framework which can enable the enforcement of the patent in practice (O’Connor, 2011). 
The enforcement aspect of patent systems relates to the efficient and effective collaboration of different public and private actors of the patent system, in order to successfully implement the law in practice (Gowers, 2006; Papageorgiadis et al., 2013). Private and public agencies that administer patents, such as a country's IP office, need to be efficient, stringent and transparent in order to guarantee that the administration process is fair, certain and predictable (de Saint-Georges and van Pottelsberghe de la Potterie, 2013). Furthermore, patent enforcement also relies on the level and extent to which the government and public enforcement authorities, such as trading standards officers and the police, are committed and motivated to allocate resources, monitor and prosecute identified cases of patent infringement (Papageorgiadis et al., 2014). Finally, enforcement also requires an effective judicial system that is efficient, fair and imposes appropriate penalties to deter convicted parties from repeating the infringement of patents (Papageorgiadis et al., 2013).

The strength of patent protection from a book law standpoint in any country can differ significantly from the strength of patent enforcement effectiveness. This is because the signing and implementation of the requirements of the TRIPS agreement by signatory countries after the year 1995 led to the extension and strengthening of patent legal protection internationally (Taubman, et al., 2012). Therefore the TRIPS agreement set a relatively equivalent standard of minimum rights to IP across the signatory countries which implemented the requirements. Nevertheless, differences in patent legal protection still exist with stronger levels of patent law protection usually offered (and advocated) by developed countries (Reichman and Dreyfuss, 2007; Roffe and Spennemann, 2014). While the TRIPS agreement included legislation that can enable the enforcement of patents, it did not, however, set any minimum standards on the extent and level of effectiveness of the enforcement of patents by public and private agencies. Therefore the strength of national patent enforcement levels varies significantly between countries (Papageorgiadis et al., 2014). While it is often 
assumed in the literature that the strength of patent enforcement is equivalent to the strength of legal protection to patents in a country, this has no longer been the case in the years following the signing of the TRIPS agreement (Papageorgiadis et al., 2014; Papageorgiadis and Sharma, 2016).

\subsection{Patent systems, FDI and spillover effects}

FDI flows into a host country generate horizontal and vertical spillovers which have positive effects on the country's economic growth (Beugelsdijk et al., 2008). This is because multinational enterprises (MNEs) use FDI in order to transfer technology and know-how directly to their subsidiaries in the host country (Branstetter et al., 2006). The technology and know-how transferred can take two forms: hard technology and soft technology (Djankov and Hoekman, 2000; Dunning, 1994). Hard technology consists of physical investment in (for example) plants, equipment, and machineries, while soft technology relates to patent related assets such as knowledge, management and organization systems, production processes and expertise (Dunning, 1994). Positive spillovers depend on the magnitude of the transfer of such technology and knowledge to the host country, and in turn the magnitude depends on the ability of the firm to gain legal protection and enforce its patent rights (Maskus, 2000).

MNEs prefer stronger levels of patent law protection and, importantly, strong patent enforcement in the host countries, in order to prevent inappropriate leakage of knowledge to a related or unrelated firm (Branstetter et al., 2006; Zhao, 2006). Typically, knowledge leakage (or its threat) can inhibit the transfer of core technologies abroad even though recent studies show that firms can profit and benefit when operating in countries that offer weak appropriability regimes (Kafouros et al., 2012; Keupp et al., 2012; Swan and Allred, 2009). Indeed, endemic knowledge leakage in a host market can discourage firms from exchanging all but the most obsolescent or peripheral of IP assets or technologies, either 
internally or via unrelated concerns (Clegg and Cross, 2000; Yang, 2012). This threat is implicit in the internalisation theory of Buckley and Casson (1976).

In contrast, in countries where patent law protection and patent enforcement are strong, firms are expected to transfer patent assets of higher quality and value to the local subsidiary (Branstetter et al., 2006; Ushijima, 2013). Firms anticipate less risk and transaction costs in their interaction with local companies, and if knowledge leakage occurs, they expect to be effective in seeking to enforce their rights in practice (Clegg and Cross, 2000; Papageorgiadis et al., 2013; Yang, 2012). Consequently, FDI flows can generate positive (intentional or unintentional) knowledge spillover - and boost the economic growth of the host country.

\subsection{Patent systems and economic growth}

Recent research has tended to focus on the effect of the strength of patent law protection on economic growth rather than the strength of patent enforcement. By not focusing on the effectiveness of patent enforcement there is a danger of missing out on one of the two elements of patent systems. Existing studies implicitly assume that a proxy for the strength of patent legal protection would also approximate to the effect of the enforcement aspect of a patent system. The strength of the two aspects comprising national patent systems, however, has varied significantly in the years following TRIPS. The strength of patent law protection has increased among WTO member countries, due to the requirements set out by TRIPS, whereas the strength of patent enforcement has not received a similar or equivalent boost (Taubman et al., 2012). This has resulted in a high divergence between the levels of patent legal protection strength and patent enforcement strength (Papageorgiadis et al., 2014). While results of studies looking at the effect of the strength of patent legal protection prior to the implementation of TRIPS may implicitly provide an indication about the effect of patent 
enforcement strength on economic growth, this has no longer been the case in the years since the signing and implementation of TRIPS.

A number of studies on the effect of the strength of patent law protection on economic growth find a highly significant positive relationship, using data covering the years prior to the signing of the TRIPS agreement (e.g. Falvey et al., 2006; Gould and Gruben, 1996), and after TRIPS implementation (Kashcheeva, 2013; Kim et al., 2012). Some existing studies, however, have not found a significant relationship between the two variables when focusing on developed and developing countries (Gould and Gruben, 1996; Schneider, 2005) or middle income countries (Falvey et al., 2006; Kim et al., 2012). Other studies have found that the strength of patent law protection has an indirect effect on economic growth which is moderated by total factor productivity (Thompson and Rushing, 1999) and R\&D activities in a cluster of developed economies (Park and Ginarte, 1997). However, Kashcheeva (2013) researched the joint effect of the strength of patent law protection and level of inward FDI, and revealed a significantly negative relationship with the economic growth of developing countries. The author also found that the joint effect had an insignificant relationship with the economic growth of developed countries, and of all countries as a whole. This negative finding contradicts the results of the existing literature and requires further attention in future empirical studies.

Given that there is currently no empirical evidence on the effect of the strength of patent enforcement on the economic growth of countries, we develop two research questions that are informed from the previously discussed related literature on the effects of the strength of patent law protection. The first research question aims to identify if patent enforcement strength has an effect on economic growth. Therefore:

$\mathrm{RQ}_{1}$ : Does the strength of patent enforcement have an effect on the economic growth of developed and developing countries? 
The second research question takes into account the negative impact that the joint effect of patent law protection strength and inward FDI levels has had on the economic growth of developing countries (Kashcheeva, 2013), and aims to identify the joint effect of patent enforcement strength and inward FDI levels on economic growth.

$\mathrm{RQ}_{2}$ : Do the effect of patent enforcement strength and the level of inward FDI have an impact on the economic growth of developed and developing countries?

\section{Empirical investigation}

The empirical investigation covers the post-TRIPS implementation years 1998-2011, and we study the effects on 42 developing and developed countries. ${ }^{6}$ The classification of countries into developed and developing is in accordance with the World Bank (2009), which identifies as developed countries those economies with a gross national income (GNI) per capita which exceeds US\$11,905; developing countries are those having a smaller GNI figure. The 27 developed economies in the sample are: Australia, Austria, Belgium, Canada, Chile, Czech Republic, Denmark, Finland, France, Germany, Greece, Hong Kong, Ireland, Israel, Italy, Japan, South Korea, Netherlands, New Zealand, Norway, Poland, Portugal, Singapore, Spain, Sweden, Switzerland and the UK. The fifteen developing economies in the sample are: Argentina, Brazil, China (PRC), Colombia, Hungary, India, Indonesia, Malaysia, Mexico, Philippines, Russia, South Africa, Thailand, Turkey and Venezuela.

\subsection{The dependent variable}

We follow previous studies in the literature and select the use of GDP per capita growth data

\footnotetext{
${ }^{6}$ The number of countries (42) included in the study was mainly determined by the availability of data provided by the Papageorgiadis et al. (2014) index. The index provides data for 48 countries, but the full data for the years 1998-2011 was available only for 43 countries. Therefore the following five countries were not considered: Iceland, Jordan, Romania, Slovakia and Ukraine. In addition, the data used to proxy for the dependent and four control variables were downloaded from the World Bank which, however, did not provide data for the Republic of China (ROC) (Taiwan). Therefore ROC was not also not considered in the empirical investigation.
} 
for the years 1998-2011 to form the dependent variable of our empirical estimations (Falvey et al., 2006; Kim et al., 2012; Park and Ginarte, 1997; Schneider, 2005; Thompson and Rushing, 1996). The data on GDP per capita growth were sourced from the World Bank (2015a).

\subsection{Explanatory variables}

The two key explanatory variables of this study are the strength of patent enforcement and inward FDI levels. With regards to patent enforcement strength, we use the composite index of patent systems' strength developed by Papageorgiadis et al. (2014). The conceptual framework underpinning this composite index follows a transaction costs rationale and identifies the strength of the enforcement-related aspects of national patent systems for the years 1998-2011. The composite index is constructed following the OECD (2008) methodology and uses factor analysis for the allocation of weights to each of the secondary variables used to calculate the index, as well as each of the three transaction costs constructs that comprise the index, namely: a) servicing costs, b) property right protection costs, and c) monitoring costs (Papageorgiadis et al., 2014). Countries scoring high on the composite index indicate strong patent systems where the enforcement of patents is effective, and low scoring countries indicate otherwise. This index is complementary to the widely-used Ginarte and Park (1997) index (discussed in the next sub-section), since it does not consider the strength of patent law protection.

The second key explanatory variable of this study uses data for FDI net inflows sourced from the World Bank (2015a). We anticipate that FDI inflows play a mediating role in the relationship between patent enforcement strength and economic growth. Following the findings of Kashcheeva (2013) on the joint effects with patent law protection strength, FDI inflows are generally found to have a positive effect on the economic growth of countries 
through the creation of (among other benefits) positive spillover effects (Borensztein et al., 1998; Li and Liu, 2005; Lipsey, 2002). We therefore allow FDI inflows to interact with the patent enforcement strength variable.

\subsection{Control variables}

The selection of the control variables used in this study is in line with the existing literature on economic growth theory (e.g. Barro, 1991; Borenztein et al., 1998; Li and Liu, 2005; Salai-Martin, 1997) and patent law protection strength and economic growth (Kim et al., 2012; Park and Ginarte, 1997). We therefore utilize six independent variables in our model, namely: i) patent law protection strength, ii) gross fixed capital formation, iii) political stability, iv) human capital, v) inflation rate and vi) research and development (R\&D) investment.

Following previous studies in the literature, we use the updated data of the Ginarte and Park (1997) composite index published by Park (2008) to control for patent law protection strength in a country. This widely used index (with more than 1600 citations to date, according to Google Scholar) quantifies the existence (or not) of patent and patent related laws in the legal framework of a country. The composite index is constructed by aggregating the unweighted scores of five patent law-related constructs. It is important to underline that while one of the five constructs of the Ginarte and Park (1997) index is called "enforcement mechanisms", this construct captures the availability of "law on the books" relating to the enforcement of patents, but it does not capture "law in action", which relates to the level and extent that the enforcement-related actors of the patent system apply and enforce the patent laws in practice (Arora, 2009; Maskus, 2000; Park, 2008). Higher scores in the index indicate countries boasting strong patent law protection.

Regarding the remaining five control variables, we use the ratio of gross fixed capital formation to GDP, available from the World Bank (2015a), as a proxy for investment. Higher 
levels of capital stock are expected to boost economic activity in a country and have a positive effect on its growth (Barro, 2003; Sala-i-Martin, 1997). We measure political stability based on the government stability construct of the International Country Risk Guide (ICRG) (PRS group, 2015). Politically stable countries are found to experience higher levels of economic growth compared to unstable ones (Barro, 2003). Furthermore, we use data on national tertiary education enrolment which are available from the World Bank (2015b) to proxy for the human capital variable in our model. A higher quality of human capital in a country is expected to have a positive impact on the economic growth of a country (Awokuse and Yin, 2010; Gould and Gruben, 1996). Inflation rate is taken from the World Bank (2015a), and it is anticipated that higher levels of inflation in a country will have a negative effect on its economic growth rate, and vice versa (Barro, 2003). Finally, we proxy for the level of $R \& D$ investment in a country using the World Bank (2015a) data on the number of R\&D researchers in a given country per million of the population, and anticipate that countries with higher levels of R\&D investment will experience higher levels of economic growth (Wang et al., 2013; Park and Ginarte, 1997).

\subsection{Model Specification}

We adopt the standard growth specification model to inform our empirical specification. Our approach involves the estimation of dynamic panel data models using the Generalised Method of Moments (GMM) framework originated by Holtz-Eakin et al. (1988) and developed by Arellano and Bond (1991) and Arellano and Bover (1995). The literature suggests that this framework is appropriate in cases with small time periods and larger cross-sectional data. In addition, the GMM approach can overcome a number of econometric problems that may be encountered during estimation, such as: bi-directional causality between variables; the possible endogeneity of explanatory variables, as well as omitted variable biases; time- 
invariant country characteristics (fixed effects), that may be correlated with the explanatory variables, and the presence of autocorrelation (Beugelsdijk et al., 2008; Bond, 2002; Caselli et al., 1996).

More specifically, the generic linear econometric form of the model utilized can be expressed as follows:

$y_{i t}=\alpha_{i}+\beta_{i} x_{i t}+\varepsilon_{i t}$,

$\varepsilon_{i t} \sim$ i.i.d. $\left(0, \sigma^{2}\right)$.

where $y_{i t}$ is the dependent variable, $\alpha_{\mathrm{i}}$ is the intercept term, $\beta_{\mathrm{i}}$ is a $\mathrm{k} \times 1$ vector of parameters to be estimated by the explanatory variables, and $\mathrm{x}_{\mathrm{it}}$ is a $1 \times \mathrm{k}$ vector of observations on the explanatory variables, $\mathrm{t}=1, \ldots, \mathrm{T}, \mathrm{i}=1, \ldots, \mathrm{N}$, and $\varepsilon_{\mathrm{it}}$ is a random term, assumed to satisfy the normal requirements.

Taking the first difference of equation (1), we get equation (2) devoid of any country specific effects:

$y_{i t}-y_{i t-1}=\beta^{\prime}\left(x_{i t}-x_{i t-1}\right)+\gamma\left(y_{i t-1}-y_{i t-2}\right)+\left(\varepsilon_{i t}-\varepsilon_{i t-1}\right)$

The inherent endogeneity of the explanatory variables as well as the correlation of the error term in equation (2) with the lagged dependent variable calls for an instrumental variable treatment. More specifically, GMM dynamic panel estimator uses the following moment conditions:

$$
\begin{aligned}
& E\left\lfloor y_{i t-s}\left(\varepsilon_{i t}-\varepsilon_{i t-1}\right)\right\rfloor=0, \text { for } \quad s \geq 2 ; t=3, . ., T . \\
& E\left\lfloor x_{i t-s}\left(\varepsilon_{i t}-\varepsilon_{i t-1}\right)\right\rfloor=0, \text { for } s \geq 2 ; t=3, \ldots, T .
\end{aligned}
$$

On the basis of the preceding conditions, the GMM estimator is referred to as the difference estimator. It has been shown that when the explanatory variables are persistent over time, lagged levels are weak instruments for the regression equation in differences (AlonsoBorrego and Arellano, 1999; Blundell and Bond, 1998). 
To reduce the potential biases and imprecision associated with the usual estimator, we opt for an estimator that combines in a system the regression in differences with the regression in levels (Arellano and Bover, 1995; Blundell and Bond, 1998). The instruments for the regression in differences are the same as above. The instruments for the regression in levels are the lagged differences of the corresponding variables. In addition, given the assumption that there is no correlation between the differences of right-hand side variables and the country-specific effects, the lagged differences of the corresponding variables can be used as instruments in the estimation process.

We use a variant of the standard two-step system estimator that controls for heteroskedasticity. Typically, the system estimator treats the moment conditions as applying to a particular time period. Obtaining consistent GMM estimators is heavily contingent upon the validity of the instruments. Ensuring that the latter is the case, we consider two specification tests suggested by Arellano and Bond (1991), Arellano and Bover (1995) and Blundell and Bond (1998). The first is a Sargan test, testing the overall validity of the instruments (i.e. no correlation between the error term and the instruments), and the second one examines the hypothesis that the error term $\varepsilon_{i t}$ is not serially correlated, (i.e. second order serial correlation). In addition to the two-step system GMM, we also generate estimates using the standard OLS and Fixed Effects (or within) specifications.

The dataset that we use covers the years 1998-2011 (annually), and consists of $\mathrm{N}$ cross-sectional units, that are denoted as $i=1, \ldots, \mathrm{N}$ observed at $\mathrm{T}$ time periods, denoted as $t=$ $1, \ldots, T$. Furthermore, $y$ is a $(T N \times 1)$ vector of endogenous variables and $x$ is a $(T N \times k)$ matrix of exogenous variables (which does not incorporate a column of units for the constant term). Therefore we have collated data for a cross-section of the 42 countries studied $(N=42)$, for 14 years $(T=14)$. We first estimate the equations using the full dataset of 42 countries and 
then divide the data in two country clusters: a cluster of 27 developed countries and a cluster of 15 developing countries.

Our primary aim is to isolate and effectively gauge the impact of the patent enforcement strength variable, as well as the mediating role of inward FDI on the relationship between patent enforcement strength and economic growth. We estimate various specifications as follows:

$g d p p c_{i t}=a_{0}+a_{1} g c f_{i t}+a_{2} f d i_{i t}+a_{3} r d_{i t}+a_{4} h c_{i t}+a_{5} i n f_{i t}+a_{6} p s_{i t}+a_{7} p a t l p_{i t}+$ $a_{8}$ paten $\left._{i t}+a_{9}(f d i * \text { patlp })_{i t}+a_{10}(f d i * \text { paten })_{i t}\right)+a_{11} g d p p c_{i t-1}+u_{i t}$

(5)

$u_{i t}=v_{i}+e_{i t}$

where $g d p p c$ is GDP per capita, $g c f$ denotes gross fixed capital formation to GDP ratio, $f d i$ is foreign direct investment flows as percentage of GDP, $r d$ stands for research and development, $h c$ is human capital, inf is inflation rate, $p s$ denotes political stability, paten is the Papageorgiadis et al., (2014) index of patent enforcement strength, patlp is the Park (2008) index of patent law protection strength, fdi*paten and $f d i^{*}$ patlp capture potential interactions between the two patent indices and FDI respectively, $u_{t}$ is the disturbance term, $v_{i}$ captures the unobserved country-specific effect, while $e_{i t}$ is the idiosyncratic error.

The definition and descriptive statistics of each variable are provided in Table 1. We control for time effects using period dummies. ${ }^{7}$ By checking both the cross correlation matrix (see Table 2) and the variance inflation factor (VIF), we have ensured that no collinear relationships are present. ${ }^{8}$

\footnotetext{
${ }^{7}$ Due to space limitations, the results for the time dummies are available on request.

${ }^{8}$ When it comes to checking for multicollinearity a rule of thumb is that a VIF exceeding 10 (or equivalently, tolerances of .10 or lower) may be a reason for concern. In the case of this study, the VIF scores were well below this figure, averaging below 4.0. (Kutner et al., 2004; O’Brien, 2007).
} 
The results reported in the next section suggest that the three different methods utilized, i.e. OLS, Fixed Effects (FE) and GMM-SYS, yield similar results. The focal point of the ensuing analysis, however, will be the GMM-SYS specification, the generated evidence of which is the most reliable estimates, as explained previously. It should also be stressed that whenever there is considerable difference between the FE and the GMM estimates (mostly in terms of the significance of the coefficients), the Hausman test is effectively applied to determine which model is the most consistent one. The robustness of our estimated coefficient for the GMM-SYS specification is confirmed by the AR(2) and Sargan tests, on the basis of which the null hypothesis of no serial correlation and instrument validity could not be rejected.

\section{Tables 1 and 2 go about here}

\section{Results and discussion}

The findings of the estimation are reported in Table 3 (full dataset), Table 4 (developed countries) and Table 5 (developing countries). Given the preceding analysis on the legitimacy as well as robustness of the GMM model, it is appropriate that we base the interpretation of our results on the GMM estimates per se.

Tables 3, 4 and 5 go about here

With regards to the first research question, the GMM estimates for all countries' datasets suggest that patent enforcement strength has an insignificant relationship with economic growth. This relationship, however, is positive and highly significant (at the 5\% level) when the developed and developing countries are considered as separate clusters. This result provides the first clear evidence that stronger levels of patent enforcement have a highly significant positive relationship with higher levels of economic growth. 
Our understanding of the effect of patent enforcement strength on economic growth is further deepened when looking at the coefficients of the interaction between patent enforcement and inward FDI flows. We find that inward FDI flows play a mediating role in the relationship between patent enforcement and economic growth, particularly for developed countries. Countries that are recipients of high levels of FDI and offer strong levels of patent enforcement experience a highly significant (at the $1 \%$ level), positive effect on their economic growth. This is evident in the cluster of developed countries and the estimations for the full dataset. The answer to the second research question, therefore, is that there is indeed a mediating positive influence of FDI on the relationship - but not in the case of developing countries.

Overall, we find strong evidence to suggest that the strength of the enforcementrelated aspects of patent systems has a strong positive effect on the economic growth of countries, particularly for developing countries. Strong levels of patent enforcement can reassure patent owners that once their patent is granted in a given country, they can seek for and effectively enforce their rights in practice if needed. This suggests that developing countries would be well advised to embrace policies that strengthen the levels of patent enforcement within the context of international trade negotiations, since these are expected to have a positive effect on their economic growth.

In addition, we find inward FDI to play a highly significant positive mediating role between patent enforcement strength and the economic growth of developed countries. The importance of the strength of patent enforcement and its cumulative effect, together with inward FDI, on economic growth should be appreciated and included in the policy recommendations aimed at helping stimulate economic growth in countries, particularly developed ones. Overall, we have clear evidence that all countries can potentially benefit 
from strengthened levels of patent enforcement, this being the case especially if they also receive high levels of FDI.

A different picture emerges when looking at the effect of patent law protection strength on economic growth. Patent law protection strength has a significant (at the 5\% level) negative effect on the economic growth of developed countries, and an insignificant effect across the full dataset of developing countries. It appears that in the years since the TRIPS agreement, the strengthening of patent law protection in developed countries may be hampering their economic growth potential. The results of this study challenge the findings of some previous studies that have identified a positive relationship (e.g. Falvey et al., 2006; Kashcheeva, 2013; Kim et al., 2012; Thompson and Rushing, 1996).

When considering the role of inward FDI in this relationship, we find two contrasting results. The estimations for the entire dataset reveal high inward FDI levels in countries boasting strong patent law protection to have a moderately significant positive mediating effect on economic growth. It therefore appears that the cumulative effect of the strength of patent law protection and inward FDI positively impacts the countries in the full dataset. However, this effect is moderately significant but negative for the developing countries of the dataset and insignificant for the developed economies. This negative evidence is in line with similar findings for developing countries reported by Kashcheeva (2013).

The results for the control variables are mostly aligned with expectations as reported in the literature. We find that gross fixed capital formation has a highly significant positive relationship with economic growth across all estimations. R\&D investments also have a positive effect on economic growth for all estimations, except for the developing countries cluster where the relationship is insignificant. The same positive relationship is also found for political stability across both estimations of the developed and developing countries, but insignificant for the estimation using the full dataset. Finally, and as expected, high levels of 
inflation rates are found to have a negative effect on economic growth, but this effect is only found to be significant in the case of all countries combined.

\section{Concluding remarks.}

This study has investigated the effect of the strength of patent enforcement in stimulating economic growth and the role of inward FDI flows in positively mediating this relationship. This is the first empirical study of the role of the strength of patent enforcement in stimulating economic growth, since previous empirical studies have focused on the effect of the strength of patent law protection using the Ginarte and Park (1997) index. The reason why previous studies did not take into consideration the level of effectiveness of patent enforcement was mainly due to the lack of available data (Arora, 2009; Papageorgiadis et al., 2014). In this study we utilize a newly-published, longitudinal index that captures the strength of the enforcement related aspects of patent systems developed by Papageorgiadis et al. (2014).

We find that stronger levels of patent enforcement have a highly significant positive effect on the economic growth of developed and developing countries. Importantly, we uncover the mediating role of inward FDI flows in positively boosting this effect for all 42 countries in our dataset and particularly for the subset of 27 developed countries. The results suggest that developing countries benefit by strengthening their levels of patent enforcement, since such reforms have highly significant positive effects on their economic growth. Our findings provide strong evidence on the relationship between the strength of the enforcement dimensions of patent systems and economic growth, and provide empirical support for the policies of national IP Offices and current international trade negotiations that now place emphasis on the strengthening of the enforcement dimension of patent systems across countries. The positive effects of the strength of patent enforcement identified are particularly 
important for developing countries that participate in international trade negotiations, but are sceptical about agreeing to adopt such policies.

Furthermore, we follow the steps of previous research and also study the effect of the strength of patent law protection on economic growth in the years after TRIPS. We find that stronger levels of patent law protection have a negative effect on the economic growth of developing countries, and an insignificant effect for all other countries. In addition, we also find that developing countries offering strong patent law protection and receiving high levels of inward FDI flows experience a negative effect on their economic growth, confirming the results of Kashcheeva (2013).

Overall, taking stock of our findings, it is important to remember that the results originate from a time period (1998-2011) when the international policy-making emphasis was mainly placed on strengthening the patent law protection levels of countries. A potential future multilateral international trade agreement (similar to TRIPS), where signatory countries uniformly push for the strengthening of patent enforcement, could lead to a very different context to that of this study, requiring further exploration. Finally, given the availability of the patent enforcement strength dataset utilized in this study, future research could further investigate the relationship between patent enforcement strength and FDI by, for example, studying the role of patent enforcement levels in stimulating FDI and vice versa. 


\section{References}

Alonso-Borrego, C. and Arellano, M. (1999), "Symmetrically normalized instrumentalvariable estimation using panel data”, Journal of Business \& Economic Statistics, Vol. 17 No. 1 , pp. 36-49.

Arellano, M. and Bond, S. (1991), "Some tests of specification for panel data: Monte Carlo evidence and an application to employment equations", The Review of Economic Studies, Vol. 58 No. 2, pp. 277-297.

Arelleno, M. and Bover, O. (1995), “Another look at instrumental variable estimation of error component models", Journal of Econometrics, Vol. 68 No. 1, pp. 29-51.

Arora, A. (2009), "Intellectual property rights and the international transfer of technology: setting out an agenda for empirical research in developing countries", in World Intellectual Property Organization (WIPO) (Ed.), The economics of intellectual property: Suggestions for further research in developing countries and countries with economies in transition, WIPO publication No 1012(E), Geneva, pp. 41-58.

Awokuse, T. O. and Yin, H. (2010), "Does stronger intellectual property rights protection induce more bilateral trade? Evidence from China's imports", World Development, Vol. 38 No.8, pp. 1094-1104.

Barro, R. J. (1991), "Economic growth in a cross section of countries”, Quarterly Journal of Economics, Vol 106 No. 2, pp. 407-443.

Barro, R. J. (2003), "Determinants of economic growth in a panel of countries", Annals of Economics and Finance, Vol. 4 No. 2, pp. 231-274.

Beugelsdijk, S., Smeets, R. and Zwinkels, R. (2008), “The impact of horizontal and vertical FDI on host's country economic growth", International Business Review, Vol. 17 No. 4 , pp. $452-472$. 
Blundell, R. and Bond, S. (1998), "Initial conditions and moment restrictions in dynamic panel data models", Journal of Econometrics, Vol 87 No. 1, pp. 115-143.

Bond, S. R. (2002), "Dynamic panel data models: a guide to micro data methods and practice", Portuguese Economic Journal, Vol 1 No. 2, pp. 141-162.

Borensztein, E., De Gregorio, J. and Lee, J. W. (1998), “How does foreign direct investment affect economic growth?”, Journal of International Economics, Vol. 45 No. 1, pp. 115135.

Branstetter, L. G., Fisman, R. and Foley, C. F. (2006), "Do stronger intellectual property rights increase international technology transfer? Empirical evidence from US firm-level panel data", The Quarterly Journal of Economics, Vol. 121 No. 1, pp. 321-349.

Buckley, P. J. and Casson, M. (1976), The future of the multinational enterprise (Vol. 1), Macmillan, London.

Caselli, F., Esquivel, G. and Lefort, F. (1996), "Reopening the convergence debate: a new look at cross-country growth empirics", Journal of Economic Growth, Vol. 1 No. 3, pp. 363-389.

Clegg, J. and Cross, A. R. (2000), “Affiliate and non-affiliate intellectual property transactions in international business: An empirical overview of the UK and USA", International Business Review, Vol. 9 No. 4, pp. 407-430.

de Saint-Georges, M. and van Pottelsberghe de la Potterie, B. (2013), “A quality index for patent systems", Research Policy, Vol. 42 No. 3, pp. 704-719.

Deere, C. (2008), The implementation game: the TRIPS agreement and the global politics of intellectual property reform in developing countries, Oxford University Press, Oxford

Djankov, S. and Hoekman, B. (2000), "Foreign investment and productivity growth in Czech enterprises", The World Bank Economic Review, Vol. 14 No. 1, pp. 49-64. 
Dunning, J. H. (1994), "Re-evaluating the benefits of foreign direct investment",

Transnational Corporations, Vol. 3 No. 1, pp. 23-51.

Electronic Frontier Foundation (2013), “Trans-Pacific partnership Agreement”, available at: https://www.eff.org/issues/tpp. (accessed 16 June, 2016).

Europa.eu. (2013a), "How much does the TTIP have in common with ACTA?" available at: http://trade.ec.europa.eu/doclib/docs/2013/july/tradoc_151673.pdf. (accessed 16 August, 2015).

Europa.eu. (2013b), “Transatlantic Trade and Investment Partnership (TTIP), the biggest trade deal in the world", available at: http://ec.europa.eu/trade/policy/in-focus/ttip/. (accessed 16 June, 2016).

Europa.eu. (2016), "India”, available at: http://ec.europa.eu/trade/policy/countries-andregions/countries/india/index_en.htm (accessed 18 September, 2016).

Falvey, R. E., Foster, N. and Greenaway, D. (2006), "Intellectual property rights and economic growth", Review of Development Economics, Vol. 10 No. 4, pp. 700-719.

Fergusson, I. F. and Vaughn, B. (2010), The Trans-Pacific Partnership Agreement, Congressional Research Service Report for Congress 7-5700, Washington, D.C.

Ghauri, P. and Rao, P. M. (2009), "Intellectual property, pharmaceutical MNEs and the developing world", Journal of World Business, Vol. 44 No. 2, pp. 206-215.

Ginarte, J. C. and Park, W. (1997), "Determinants of patent rights: a cross-national study”, Research Policy, Vol. 26, pp. 283-301.

Gould, D. M. and Gruben, W. C. (1996), “The role of intellectual property rights in economic growth", Journal of Development Economics, Vol. 48 No. 2, pp. 323-350.

Gowers, A. (2006), “Gowers review of intellectual property”, available at: www.officialdocuments.gov.uk/document/other/0118404830/0118404830.pdf. (accessed 20 June, 2016). 
Hargreaves, I. (2011), "Digital opportunity: a review of intellectual property and growth", available at: www.ipo.gov.uk/ipreview-finalreport.pdf. (accessed 20 June, 2016).

Holtz-Eakin, D., Newey, W. and Rosen, H. S. (1988), "Estimating vector autoregressions with panel data", Econometrica: Journal of the Econometric Society, Vol. 56, pp. 13711395.

Kafouros, M. I., Buckley, P. J. and Clegg, J. (2012), “The effects of global knowledge reservoirs on the productivity of multinational enterprises: The role of international depth and breadth", Research Policy, Vol 41 No. 5, pp. 848-861.

Kashcheeva, M. (2013), "The role of the intellectual property rights in the relation between foreign direct investment and growth", Oxford Economic Papers, Vol. 65, pp. 699-720.

Keupp, M. M., Friesike, S. and von Zedtwitz, M. (2012), "How do foreign firms patent in emerging economies with weak appropriability regimes? Archetypes and motives", Research Policy, Vol 41 No. 8, pp. 1422-1439.

Kim, Y. K., Lee, K., Park, W. G. and Choo, K. (2012), “Appropriate intellectual property protection and economic growth in countries at different levels of development", Research policy, Vol. 41 No. 2, pp. 358-375.

Kutner, M. H., Nachtsheim, C. and Neter, J. (2004), Applied linear regression models, McGraw-Hill/Irwin.

Li, X. and Liu, X. (2005), "Foreign direct investment and economic growth: an increasingly endogenous relationship", World Development, Vol. 33 No. 3, pp. 393-407.

Lipsey, R. E. (2002),“Home and host country effects of FDI”, NBER working paper 9293, Cambridge, MA.

Maskus, K. E. (2000), Intellectual property rights in the global economy, Institute for International Economics, Washington D.C. 
O'Brien, R. M. (2007), “A caution regarding rules of thumb for variance inflation factors", Quality \& Quantity, Vol. 41 No. 5, pp. 673-690.

O'Connor, T. S. (2011), "Development of intellectual property laws for the Russian Federation”, Journal of Business Research, Vol. 64 No. 9, pp. 1011-1016.

Papageorgiadis, N., Cross, A. R. and Alexiou, C. (2013), "The impact of the institution of patent protection and enforcement on entry mode strategy: A panel data investigation of U.S. firms", International Business Review, Vol. 22 No. 1, pp. 278-292.

Papageorgiadis, N., Cross, A. R. and Alexiou, C. (2014), “International patent systems strength 1998-2011", Journal of World Business, Vol. 49 No. 4, pp. 586-597.

Papageorgiadis, N. and Sharma, A. (2016), "Intellectual property rights and innovation: A panel analysis", Economics Letters, Vol. 141, pp. 70-72.

Park, W. (2008), “International patent protection 1960-2005”, Research Policy, Vol. 37 No. 4, pp. 761-766.

Park, W. and Ginarte, C. (1997), "Intellectual property rights and economic growth", Contemporary Economic Policy, Vol. 15 No. 3, pp. 51-61.

Pathak, S., Xavier-Oliveira, E. and Laplume, A. O. (2013), "Influence of intellectual property, foreign investment, and technological adoption on technology entrepreneurship", Journal of Business Research, Vol. 66 No. 10, pp. 2090-2101.

PRS Group (2015), “International country risk guide”, available at: www.adbi.org/3rdpartycdrom/2004/12/01/1359.international.country.risk/. (accessed 20 June, 2016).

Reichman, J. H. and Dreyfuss, R. C. (2007), “Harmonization without consensus: Critical reflections on drafting a substantive patent law treaty", Duke Law Journal, Vol. 57 No. 1, pp. 85-130. 
Roffe, P. and Spennemann, C. (2014), "Preferential trade agreements and intellectual property rights”, in Cimoli, M., Dosi, G., Maskus, K. E., Okediji, R. L., Reichman, J. H. and Stiglitz, J. E. (Eds.), Intellectual Property Rights: Legal and Economic Challenges for Development, Oxford University Press, Oxford, pp. 439-476.

Sala-i-Martin, X. X. (1997), "I just ran two million regressions”, The American Economic Review, Vol. 87 No. 2, pp. 178-183.

Schneider, P. H. (2005), "International trade, economic growth and intellectual property rights: A panel data study of developed and developing countries", Journal of Development Economics, Vol. 78 No. 2, pp. 529-547.

Swan, K. S. and Allred, B. B. (2009), "Does 'the China Option' influence subsidiary technology sourcing strategy?", Journal of International Management, Vol. 15 No. 2 , pp. 169-180.

Taubman, A., Wager, H. and Watal, J. (Eds.) (2012), A handbook on the WTO TRIPs agreement, Cambridge University Press, Cambridge.

Thompson, M. A. and Rushing, F. W. (1996), “An empirical analysis of the impact of patent protection on economic growth", Journal of Economic Development, Vol. 21 No. 2, pp. 61-79.

Thompson, M. A. and Rushing, F. W. (1999), “An empirical analysis of the impact of patent protection on economic growth: an extension”, Journal of Economic Development, Vol. 24 No. 1 , pp. 67-76.

UK Intellectual Property Office (2011), “The UK's International Strategy for Intellectual Property", available at:

https://www.gov.uk/government/uploads/system/uploads/attachment_data/file/32562/ipres ponse-international.pdf (accessed 20 June, 2016). 
United Nations Conference of Trade and Development (1996), The TRIPs agreement and developing countries, UNCTAD/ITE/1, United Nations, New York and Geneva.

United Nations Conference on Trade and Development (2013), World investment report 2013. Global value chains: investment and trade for development, United Nations, New York and Geneva.

Ushijima, T. (2013), "Patent rights protection and Japanese foreign direct investment", Research Policy, Vol. 42 No. 3, pp. 738-748.

USTR (United States Trade Representative) (2013), “The United States in the Trans Pacific Partnership", available at: http://www.ustr.gov/about-us/press-office/factsheets/2011/november/united-states-trans-pacific-partnership (accessed 20 June, 2016).

Wang, D. H. M., Yu, T. H. K. and Liu, H. Q. (2013), "Heterogeneous effect of high-tech industrial R\&D spending on economic growth", Journal of Business Research, Vol. 66 No. 10, pp. 1990-1993.

World Bank (2009), "How we classify countries”, available at: http://data.worldbank.org/about/country-classifications (accessed 20 June, 2016).

World Bank (2015a), “World Bank Open Data”, available at: http://data.worldbank.org. (accessed 20 June, 2016).

World Bank (2015b), "School enrolment, tertiary (\% gross)" available at: http://data.worldbank.org/indicator/SE.TER.ENRR. (accessed 20 June, 2016).

WTO (World Trade Organization) (2013), "Responding to least developed countries' special needs in intellectual property", available at:

http://www.wto.org/english/tratop_e/trips_e/ldc_e.htm (accessed 16 June, 2016).

Yang, D. (2008), "Pendency and grant ratios of invention patents: A comparative study of the US and China", Research Policy, Vol. 37 No. 6, pp. 1035-1046. 
Yang, D. (2012), “Arm's length and captive transactions: patent-based view of control in internationalization”, International Business Review, Vol. 21 No. 4, pp. 575-587.

Yang, D., and Sonmez, M. (2013), "Integration and divergence of patent systems across national and international institutions”, Journal of World Business, Vol. 48 No. 4, pp. 527 538.

Zhao, M. (2006), “Conducting R\&D in countries with weak intellectual property rights protection”, Management Science, Vol. 52 No. 8, pp. 1185-1199.

Ziedonis, R. H. (2003), "Patent litigation in the US semiconductor industry”, in W. M. Cohen and S. A. Merrill (Eds.), Patents in the knowledge based economy, The National Academies Press, Washington, DC, pp. 180-216. 
Table 1. Definition and descriptive statistics of each variable

\begin{tabular}{lcccc}
\hline \multicolumn{1}{c}{ Variables } & Mean & S.D. & Max & Min \\
\hline gdppc: GDP per capita growth (annual; \%) & 3.1 & 3.6 & 13.6 & -13.1 \\
gcf: Gross fixed capital formation/GDP (\%) & 23.3 & 6.5 & 48.6 & 10.9 \\
ps: Political stability (ICRG; index 0-12) & 8.9 & 1.5 & 12 & 5.1 \\
fdi: FDI net inflows/GDP & 5.4 & 10.8 & 38.7 & -16.4 \\
hc: Gross enrolment ratio (\%) & 52.1 & 20.5 & 103.8 & 6.1 \\
inf: Inflation rate (consumer price index; \%p.a.) & 8.3 & 11.9 & 85.7 & -4.1 \\
r\&d: Researchers in R\&D per million of & 2555 & 1844 & 8007 & 49 \\
population \\
patlp: Patent law protection strength (Park
\end{tabular}

Note: ${ }^{1}$ Gross Enrolment Ratio (GER): The values of GER can surpass the $100 \%$ because the data includes over-aged and under-aged students. This is due to early or late school entrance and grade repetition (World Bank, 2014b). 
Table 2. Correlation matrix

\begin{tabular}{llllllllll}
\hline & $\boldsymbol{g d p p c}$ & $\boldsymbol{g c f}$ & $\boldsymbol{p s}$ & $\boldsymbol{f d i}$ & $\boldsymbol{h c}$ & $\boldsymbol{i n f}$ & $\boldsymbol{r d}$ & $\boldsymbol{i p r l p}$ & ipren \\
\hline gdppc & 1 & & & & & & & & \\
$\boldsymbol{g c f}$ & 0.19 & 1 & & & & & & & \\
$\boldsymbol{p s}$ & 0.26 & 0.21 & 1 & & & & & & \\
$\boldsymbol{f d i}$ & 0.45 & 0.32 & 0.17 & 1 & & & & & \\
$\boldsymbol{h c}$ & 0.48 & 0.29 & 0.11 & 0.31 & 1 & & & & \\
inf & 0.26 & 0.24 & 0.19 & 0.28 & -0.14 & 1 & & & \\
r\&d & 0.17 & 0.21 & 0.22 & 0.27 & 0.32 & -0.17 & 1 & & \\
patlp & -0.48 & 0.31 & 0.18 & 0.32 & -0.26 & -0.11 & 0.29 & 1 & \\
paten & 0.31 & 0.26 & -0.12 & 0.27 & 0.46 & -0.16 & 0.27 & 0.33 & 1 \\
\hline
\end{tabular}


Table 3. Results for all countries

\begin{tabular}{|c|c|c|c|}
\hline & OLS & Fixed Effects & GMM-SYS \\
\hline GDP per capita ${ }_{\mathrm{t}-1}$ & $0.082(0.253)$ & $-0.026(0.058)$ & $0.024(0.005)^{* * *}$ \\
\hline Gross Fixed Capital & $0.444(0.0621)^{* * *}$ & $0.538(0.138)^{* * *}$ & $0.515(0.515)^{* * *}$ \\
\hline Political Stability & $0.086(0.053)$ & $0.118(0.071)^{*}$ & $0.014(0.081)$ \\
\hline FDI & $0.133(0.079)^{*}$ & $0.291(0.146)^{* *}$ & $0.366(0.153)^{* *}$ \\
\hline Human Capital & $0.044(0.024) *$ & $0.071(0.081)$ & $0.052(0.045)$ \\
\hline Inflation Rate & $-0.091(0.093)$ & $-0.034(0.034)^{* *}$ & $-0.034(0.014)^{* *}$ \\
\hline LnR\&D & $0.053(0.124)$ & $0.110(0.052)^{* *}$ & $0.193(0.064)^{* * *}$ \\
\hline Patent law protection & $0.154(0.075)^{* *}$ & $-0.078(0.165)$ & $0.053(0.247)$ \\
\hline Patent enforcement & $0.074(0.077)$ & $0.529(0.261)^{* *}$ & $0.755(0.737)$ \\
\hline $\begin{array}{l}\text { FDI*Patent law } \\
\text { protection }\end{array}$ & $0.016(0.077)$ & $0.127(0.138)$ & $0.254(0.153)^{*}$ \\
\hline $\begin{array}{l}\text { FDI*Patent } \\
\text { enforcement }\end{array}$ & $(0.03)^{* *}$ & $0.051(0.040)$ & $0.058(0.025)^{* *}$ \\
\hline Constant & $-0.906(0.353) * * *$ & $-1.830(0.532) * * *$ & $0.982(0.344)^{* *}$ \\
\hline $\mathrm{R}^{2}$ & 0.35 & 0.36 & - \\
\hline $\operatorname{AR}(1) p$-value ${ }^{(1)}$ & & & 0.051 \\
\hline $\operatorname{AR}(2) p$-value ${ }^{(2)}$ & & & 0.530 \\
\hline Sargan p-value ${ }^{(3)}$ & & & 0.243 \\
\hline $\begin{array}{l}\text { K-P rank Wald } \\
\text { test }^{(4)}\end{array}$ & & & 0.000 \\
\hline
\end{tabular}

No. of instruments

${ }^{(1)}$ Test for first order serial correlation (p-values); ${ }^{(2)}$ Test for second order serial correlation (p-values); ${ }^{(3)}$ Tests the null hypothesis of the appropriate set of instruments. ${ }^{(4)}$ Kleibergen-Paap rk Wald F - The results indicate that there is no under-identification problem for the difference model. A Hausman test between fixed effects and GMM-SYS indicates that GMM-SYS estimates are consistent $\left(X^{2}\right)=38.97$ and $\mathrm{p}$-value $=$ 0.032). Robust (HAC) standard errors have been used in the estimation of both OLS and Fixed Effects models; Time dummies have been used in the estimation; $(*),(* *)$ and $(* * *)$ denote significance at $10 \%, 5 \%$ and $1 \%$ level respectively; standard errors are given in parentheses. 
Table 4. Results for the cluster of developed countries

\begin{tabular}{|c|c|c|c|}
\hline Variables & OLS & Fixed Effects & GMM-SYS \\
\hline GDP per capitat & $0.293(0.085)^{* * *}$ & $0.294(0.091)^{* * *}$ & $0.535(0.080)^{* * *}$ \\
\hline Gross Fixed Capital & $0.123(0.042)^{* * *}$ & $0.180(0.080)^{* *}$ & $0.373(0.131)^{* * *}$ \\
\hline Political Stability & $0.039(0.038)$ & $0.082(0.060)$ & $0.202(0.082)^{* *}$ \\
\hline FDI & $0.094(0.116)$ & $0.135(0.116)$ & $0.107(0.031)^{* * *}$ \\
\hline Human Capital & $0.018(0.022)$ & $0.039(0.091)$ & $0.097(0.174)$ \\
\hline Inflation Rate & $-0.009(0.011)$ & $-0.011(0.013)$ & $-0.082(0.164)$ \\
\hline LnR\&D & $0.043(0.022)^{*}$ & $0.088(0.016)^{* * *}$ & $0.231(0.066)^{* * *}$ \\
\hline Patent law protection & $-0.197(0.595)$ & $-0.207(0.185)$ & $-0.608(0.260)^{* *}$ \\
\hline Patent enforcement & $0.172(0.178)$ & $0.192(0.113)^{*}$ & $0.091(0.042)^{* *}$ \\
\hline $\begin{array}{l}\text { FDI*Patent law } \\
\text { protection }\end{array}$ & $-0.016(0.123)$ & $-0.061(0.122)$ & $-0.090(0.099)$ \\
\hline $\begin{array}{l}\text { FDI*Patent } \\
\text { enforcement }\end{array}$ & 6) & $0.134(0.067)^{* *}$ & $0.049(0.015)^{* * *}$ \\
\hline Constant & $-0.310(0.195)$ & $-0.119(0.599)$ & $-0.887(0.872)$ \\
\hline $\mathrm{R}^{2}$ & 0.29 & 0.31 & - \\
\hline $\operatorname{AR}(1)^{(1)}$ & & & 0.031 \\
\hline $\operatorname{AR}(2)$ & & & 0.498 \\
\hline Sargan $^{(3)}$ & & & 0.561 \\
\hline $\begin{array}{l}\text { K-P rank Wald } \\
\text { test }^{(4)}\end{array}$ & & & 0.000 \\
\hline No. of instruments & & & 32 \\
\hline
\end{tabular}

${ }^{(1)}$ Test for first order serial correlation (p-values); ${ }^{(2)}$ Test for second order serial correlation (p-values); ${ }^{(3)}$ Tests the null hypothesis of the appropriate set of instruments. ${ }^{(4)}$ Kleibergen-Paap rk Wald F - The results indicate that there is no under-identification problem for the difference model. A Hausman test between fixed effects and GMM-SYS indicates that GMM-SYS estimates are consistent $\left(\mathrm{X}^{2}\right)=27.65$ and $\mathrm{p}$-value = 0.047). Robust (HAC) standard errors have been used in the estimation of both OLS and Fixed Effects models; Time dummies have been used in the estimation; $(*),(* *)$ and $(* * *)$ denote significance at $10 \%, 5 \%$ and $1 \%$ level respectively; standard errors are given in parentheses. 
Table 5. Results for the cluster of developing countries

\begin{tabular}{|c|c|c|c|}
\hline Variables & OLS & Fixed Effects & GMM-SYS \\
\hline GDP per capita $a_{t-1}$ & $-0.005(0.025)$ & $0.088(0.057)$ & $0.116(0.052)^{* *}$ \\
\hline Gross Fixed Capital & $0.232(0.115)^{* *}$ & $0.138(0.068)^{* *}$ & $0.280(0.106)^{* * *}$ \\
\hline Political Stability & $0.398(0.172)$ & $0.552(0.218)^{* *}$ & $0.289(0.091)^{* * *}$ \\
\hline FDI & $0.104(0.053)^{* *}$ & $0.143(0.079)^{*}$ & $0.156(0.082)^{*}$ \\
\hline Human Capital & $0.055(0.027)^{*}$ & $0.039(0.119)$ & $0.060(0.042)$ \\
\hline Inflation Rate & $-0.030(0.026)$ & $-0.027(0.037)$ & $-0.010(0.025)$ \\
\hline LnR\&D & $-0.014(0.018)$ & $0.267(0.085)^{* * *}$ & $0.011(0.018)$ \\
\hline Patent law protection & $0.217(0.089)^{* *}$ & $0.002(0.994)$ & $-0.063(0.085)$ \\
\hline Patent enforcement & $0.022(0.092)$ & $0.619(0.347)^{*}$ & $0.227(0.113)^{* *}$ \\
\hline $\begin{array}{l}\text { FDI*Patent law } \\
\text { protection }\end{array}$ & $0.130(0.115)$ & $-0.040(0.152)$ & $-0.164(0.09)^{*}$ \\
\hline $\begin{array}{l}\text { FDI*Patent } \\
\text { enforcement }\end{array}$ & $0.101)$ & $-0.111(0.122)$ & $0.108(0.076)$ \\
\hline Constant & $-1.132(0.477)^{* *}$ & $-1.990(0.724)^{* * *}$ & $-1.341(0.365)^{* *}$ \\
\hline & 0.30 & 0.33 & - \\
\hline $\operatorname{AR}(1)^{(1)}$ & & & 0.029 \\
\hline $\operatorname{AR}(2)^{(2)}$ & & & 0.739 \\
\hline Sargan $^{(3)}$ & & & 0.103 \\
\hline $\begin{array}{l}\text { K-P rank Wald } \\
\text { test }^{(4)}\end{array}$ & & & 0.000 \\
\hline No. of instruments & & & 31 \\
\hline \multicolumn{4}{|c|}{$\begin{array}{l}\text { Test for first order serial correlation (p-values); }{ }^{(2)} \text { Test for second order serial correlation (p-values); }{ }^{(3)} \text { Tests } \\
\text { the null hypothesis of the appropriate set of instruments. }{ }^{(4)} \text { Kleibergen-Paap rk Wald F - The results } \\
\text { indicate that there is no under-identification problem for the difference model. A Hausman test between } \\
\text { fixed effects and GMM-SYS indicates that GMM-SYS estimates are consistent }\left(X^{2}\right)=34.65 \text { and p-value }= \\
0.038) \text {. Robust (HAC) standard errors have been used in the estimation of both OLS and Fixed Effects models; } \\
\text { Time dummies have been used in the estimation; }\left({ }^{*}\right),(* *) \text { and }(* * *) \text { denote significance at } 10 \%, 5 \% \text { and } 1 \% \\
\text { level respectively; standard errors are given in parentheses. }\end{array}$} \\
\hline
\end{tabular}

